\title{
Detection of Newcastle Disease Virus in Wild Pigeon by Serological Test in Sumel Region \\ https://doi.org/10.32792/utq/utj/vol10/1/2
}

\author{
Dyar Adil Morad AL-Barwary \\ Department of Pathology and Microbiology ,Faculty of Veterinary Medicine \\ ,University of Duhok, Kurdistan Region, Iraq.
}

\begin{abstract}
The present study aims to investigation for Newcastle disease (ND) in wild pigeons was carried out in 100 serum sample were examined for evaluating of Antibody titers. Haemagglutination-inhibition (HI) was used for detection and quantification of antibodies against Newcastle Disease (ND) virus .The results showed that $(\mathrm{NDV})$ were detected in $17 \%(\mathrm{n}=100)$ of serum samples collected from pigeons, while $83 \%$ non-detectable of (NDV) antibodies. Studies have shown that pigeons are susceptible to NDV. The risk of the transmission of NDV pigeons to poultry. Therefore there is a need to conduct regular and strategic vaccination programs against ND for poultry.
\end{abstract}

Key words: Newcastle Disease Virus, Wild Pigeon, Antibody, HA,HI test.

\section{Introduction}

Newcastle disease (ND) is a highly contagious viral disease of Poultry, wild and captive birds with high morbidity and mortality caused by the serotype avian paramyxovirus type I (APMV-I), member of the genus Avulavirus in the family Paramyxoviridae (Beard etal.,1984, Mayo,2002).In Iraq, (Al-Jumaily et al., 1989) presented evidence that the population of the rock pigeon carry such dangerous disease agents as the bacterium Salmonella typhimurium and Newcastle virus. However (Alexander et al., 1984) reported that the spread of ND virus to chickens has occurred in several countries as a result of feed contaminated by the feces of ND infected pigeons as well as (Dilaveris et al.,2007) reported that unvaccinated birds can become infected by NDV of pigeon origin, as exemplified by the 2006 case of ND in Scotland. Over 200 species of birds have been reported to be susceptible to natural

and/or experimental infection with ND virus and it seems probable that more are fully susceptible (Alexander, 1999). Although many species of bird are susceptible to ND it occurs mainly in galliformes such as pheasants, partridges and quails and also in birds of prey, including owls, pigeons and psittaciformes. In most species of bird the young are more susceptible than the adult (Arnall and Keymer, 1975). It is characterized by nasal and ocular discharge, yellowish to greenish diarrhea, sneezing, coughing, drooping of wings, twisting of head, drop in egg production and thin shelled eggs, complete paralysis, weakness and sudden death (Chansiripomchai and Sasipreyayan, 
2006; Roy and Chamham, 2007). Pigeons are amongst the most prevalent and readily observable birds in all provinces of Iraq. Besides constituting small part of human food, they are used for ornamental or appearance purposes (fancy pigeons) as well as pets, human sport (racers and performers), for biological and medical experimentations, and for teaching the art of taxidermy. Pigeons in this part of the world also have a rich historical and anecdotal background, More importantly, pigeons pose a serious health threat to millions of people and some of their economic animals. However the study aimed to investigate of NDV in wild pigeons.

\section{Materials and Methods}

Study area: The wild pigeons included in this study were survived on the building of two faculties (Agriculture and Veterinary Medicine) at University of Duhok which located in Sumel district, west of Duhok City, Kurdistan region, Iraq. A total of 100 Adults different aged pigeons were captured with a fine mesh net at different times between March and August 2012. Thereafter, the pigeons were caged and taken to the Animal house at faculty of Veterinary Medicine.

Serum collection: 100 blood samples were aseptically collected from brachial vein (wing vein) of pigeons, $2 \mathrm{ml}$ of fresh blood put in a test tube without anticoagulant from each bird then centrifuged at 1500 r.p.m, then the serum was separated and stored at freezing $\left(-20^{\circ} \mathrm{C}\right)$ till time of tests.

\section{Serological Procedure:}

Preparation of washed red blood cells : $3 \mathrm{ml}$ of blood was collected from chicken (free from pathogens),put in test tube contains $1 \mathrm{ml}$ of sodium citrate (4\% solution) as an anticoagulant, then Centrifuge the whole blood at $3000 \mathrm{rpm}$ for 5 minutes Remove plasma and buffy coat layer. $5 \mathrm{ml}$ of normal saline $(1 \% \mathrm{NaCl})$ with was added to volume of the red cells, and invert the tube to mix. Centrifuge for 5 minutes at $2000 \mathrm{rpm}$ and discard the supernatant. Then repeat adding of normal saline for 3 washes or until the supernatant is clear Completely remove the supernatant and freeze the red cells at $-20^{\circ} \mathrm{C}$, (Allan and Gough, 1974)

Haemagglutination test (HA): The HA titres of the ND antigen were determined and diluted to contain 4-HA units. This concentration was used for the HI test as described by (Allan and Gough, 1974), and (Allan et al.,1978), In this test ( LaSota strain) of NDV was used as the source of antigen for the HI test using 4 haemagglutinating(HA) units through using microtiter plate consist of 96 wells $\mathrm{V}$ shaped -bottom microtiter plate.

1-0.025 $\mathrm{ml}$ of isotonic solution (normal saline) were added to all wells (96) equally via using multiple channel micropipete.

2-0.025 $\mathrm{ml}$ of lasota strain (Antigen) was added to the first well of each row of column 1 then making several dilution applied until reaching the last well. 
3-0.025 $\mathrm{ml}$ of washed $\mathrm{RBCs}(1 \%)$ were added to all wells ,then shaking the plat in all direction via using shaker instrument after that the plat put in incubator $37 \mathrm{C}^{\circ}$ for 15 mints then the result was recorded. Furthermore the last column of each microtiter plate used for control positive and negative in case positive control 3 wells Contains normal saline ,Ag and WRBCs) which represented as a hazy film of red blood cells, no button or a very a small button of red blood cells at the bottom of the V-bottom wells. another 3 wells negative control Contains( Normal saline and WRBCs) .which showing that A sharp button of red blood cells at the bottom of the V-bottom wells.

Haemagglutination Inhibition test (HI): The HI tests were done by the betaprocedure in V-bottom microtiter plate as described(Stephan and Beard 1998).thawing of serum samples at $56 \mathrm{C}^{\mathrm{o}}$, the titer of Abs in serum sample were evaluated against (NDV) as follow.

1-0.025 $\mathrm{ml}$ of isotonic solution (normal saline ) were added to all wells (96) equally via using multichannel micropipete .

2-0.025 $\mathrm{ml}$ of serum sample for (case 1) was added to the first well of each row of column 1 then making several dilution for serum across the microtiter plate until reaching the last well.

3-0.025 $\mathrm{ml}$ of $4 \mathrm{HAU}$ of virus/antigen volume were added to all wells and mix gently then put it in side incubator for 15 minutes at $37 \mathrm{C}^{\circ}$ or leave it in minimum of 30 minutes at room temperature or 60 minutes at $4^{\circ} \mathrm{C}$.

4-0.025 $\mathrm{ml}$ of washed RBCs $(1 \%)$ were added to all wells via using multichannel microtiters ,then shaking the plat in all direction via using shaker instrument after that the plat put in incubator $37 \mathrm{C}^{\circ}$ for 30 mints then the titers was recorded. Further more the last column of each microtiter plate used for control positive and negative in case positive control 3 wells Contains (normal saline, Ag,Ab and WRBCs) which showing that A sharp button of red blood cells at the bottom of the V-bottom wells. another 3 wells negative control Contains( Normal saline ,Ag and WRBCs). which represented as a hazy film of red blood cells, no button or a very a small button of red blood cells at the bottom of the V-bottom wells. The HI titre for each bird was determined and expressed in $\log 2$, and the geometric mean for each species was calculated. An HI titre $\geq 2 \log 2$ was considered positive.

\section{Results}

1- Clinical symptoms: during the process of inspection and examination of pigeons several abnormal clinical signs were seen like emaciation, weakness ,turtle of neck, inappetance ,lameness ,ruffled feathers ,diarrhea ,depression, nasal discharge, ataxia and reluctant to move.

2- The result of HI test on the sera is showed that out of the 100 sera samples screened for NDV in wild pigeons, 17 (17\%) sera samples representing were positive for NDV-HI antibodies while $83(83 \%)$ sera samples were negative. 


\section{Discussion}

There was serological evidence of NDV antibodies in pigeons in presented study. This might be due to occasional visits of these birds to the poultry premises where they could have contracted the virus from materials from poultry houses Research farm and mixing of wild pigeon with domesticated birds of nearing village (were the infection of ND is endemic). Pigeons and doves are among a group of domesticated birds that were primarily affected by the third panzootic of ND which apparently arose in the Middle East in the late 1970s (Kaleta et al.,1985). The disease spread to all parts of the world, largely as a result of contact between birds atraces and shows and the large international trade in such birds (Biancifiori and Fioroni, 1983).In Iraq (Anton AL-Bana et al., 2007) showed that in a study about isolation and identification of Newcastle disease virus from wild pigeons there is no detectable of $\mathrm{Ab}$ titers by using (HI) test directly, with finding of clinical signs of disease this may be due to acute infection. On the basis of ND virulence, Newcastle disease virus (NDV) has been classified into three strains viz. velogenic, mesogenic and lentogenic. These strains produce highly acute, moderate and mild type of infection in poultry, respectively (Saif, 2003), as well as present study detectable of Ab titers, another study (kamas,1981) reported that pigeons infected experimentally with NDV which mean the infection could be transmitted from pigeons to poultry. While a study in Tanzania Phlemon (2010) results showed that $10 \%$ of serum sample were positive of NDV in domesticated pigeons due to mixing with poultry. In Nigeria (Fagbohun et al(2000) represented that there was no serological evidence of ND in pigeons his work, this may be due dealing with small number of pigeons.

\section{Conclusion}

Wild pigeons can tolerate certain disease agents as well as reservoir for spreading many parasitic and microbial species to other types of birds especially (Poultry), without displaying gross pathological changes and clinical signs of sickness. Therefore, eradication of pigeons from around the poultry breeding and layer farms as well as from food and water handling facilities is an essential factor for counteracting disease dissemination.

\section{References:}

- Alexander, D. J. (1999): Paramyxoviridae (Newcastle disease and others) In: Poultry Diseases. 4th ed. (Jordan, F.T.W, M. Pattison,m Eds.) W. D. Saunders and Company Limited London. PP. 139-155.

- Alexander, D. J., Pearson G., Marshal R.(1984). Infection of Fowls with Newcastle Disease Virus By Food Contaminated with Pigeon Feces. Vet. Rec. 115, 601-602.

- Al-Jumaily WT., Al-Atar MA., Al-Tae AR., Mansour AD., Jiad JH., Abdul-Latif H,(1989). The Incidence of Salmonellae and Serological Evidence 


\section{University of Thi-Qar Journal Vol.10 No.1 Mar 2015}

Web Site: https://jutq.utq.edu.iq/index.php/main Email: journal@jutq.utq.edu.iq

of Newcastle Disease in Some Wild Birds From Baghdad area. J Biol Sci ; 20: 213-9.

- Allan,W.H., Gough R. E. A. (1974).Standard Haemagglutination Inhibition Test for Newcastle Disease: A comparison of macro and micro methods.Vet. Rec. 95, 120-123.

- Allan,W.H., Lancaster J. E., Toth B. (1978). Newcastle Disease Vaccines. Their Production and Use: FAO Animal Production and Health Series, No. 106 pp. 50-69.

- Anton Sabri AL-bana, Aida Bara Allawe ,Ameen Ahmed Sebbar, (2007). Isolation \&Identification of Newcastle Disease Virus From Wild Pigeons. Iraqi vet journal issue31,No:2.

- Arnall, L., Keymer I. P. (1975): Bird Diseases. Baillere and Tindall, 8 Henrietta .Street London PP. 451-459.

- Beard, C.W. and Hanson, R.P. (1984). Newcastle disease. In: "Diseases of Poultry". Eds. By Hofstad, M.S. and Yoder, H.W. Jr. 8th ed. Iowa State University Press, Ames, Iowa, U.S.A. pp. 425-470.

- Biancifiori, F., and Fioroni, A. (1983): Anoccurrence of Newcastle disease in pigeons: Virological and serological studies on the isolates.Comp. Immunol. Microbiol. Infect. Dis., 6:247-252.

- Chansiripomchai N and Sasipreyayan J. (2006). Efficacy of Live B1 or Ulster 2c Newcastle Disease Vaccines Simultaneously Vaccinated with Inactivated Oil Adjuvant Vaccine for Protection of Newcastle Disease Virus in Broiler Chickens. Acta Vet. Scand 48:1-4.

- Dilaveris, D., Chen C., Kaiser P., Rusell P. H. (2007). The Safety and Immunogenicity of an in Ovo Vaccine Against Newcastle Disease Virus Differ Between Two Lines of Chicken. Vaccine 25, 3779-3799.

- Fagbohun O. A., Oluwayelu D.O., Owoade A.A., \& Olayemi F.O.(2000) Survey For Antibodies TO Newcastle Disease Virus In Cattle Egrets, Pigeons And Nigerian Laughing Doves. Afr. J. Biomed. Res. Vol 3; 193-194

- Mayo, M.A. (2002). Virus Taxonomy. Archives of Virology 147, 1071-1076. doi:10.1007/s007050200036.

- Phlemon N. Wambura,(2010). Detection of Antibody to Newcastle Disease Virus in Semi Domesticated Free-range Birds (Numida meleagris and Columba livia Domestica) and the risk of transmission of Newcastle disease to village chickens - short communicationa. Veterinarski Arhiv 80 (1), 129-134

- Kamas A.Jawad, (1981). STUDY OF SOME PATHOLOGICAL LESION OF NEWCASTLE DISEASE IN PIGEONS EXPPERIMENTAL INFECTION . M.Sc thesis's, college of vet medicine, Uni-Baghdad

- Kaleta, E.F. Alexander, D.J. and Russell, P.H.(1985): The first isolation of the PMV-1 virus responsible for the current panzootic in pigeons.Avian Pathol. 14: $553-557$ 
Web Site: https://jutq.utq.edu.iq/index.php/main Email: journal@jutq.utq.edu.iq

- Roy S, Chamham HVS, (2007). Poultry Disease Diagnosis and Treatment 3rd edition pp 56-62.

- Saif,Y.M.,(2003)Diseases of Poultry.11th Ed.Iowa State Univ.Press, Iowa, USA.

- Stephan, G.T. and Beard, C.W. (1998) Serologic Procedures. In: "Isolation and Identification of Avian Pathogens." Eds. By Swayne, D.E.; Glisson, J.R.; Jackwood, M.W.; Pearson,J.E. and Reel, W.M. 4th Ed. American Association of Avian Pathologists. USA. Pp:246-269.

الخلاصة

هذه الدراسة تهدف لغرض الكثف عن المرض نيوكاسل (الفايروسي) في الحمامات البرية .اخذت الحئ 100

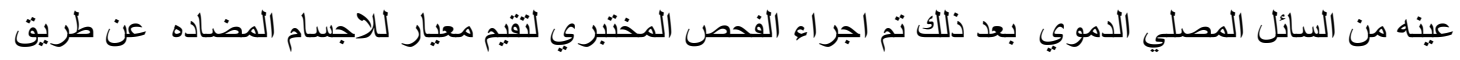

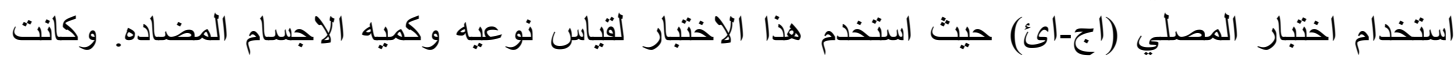

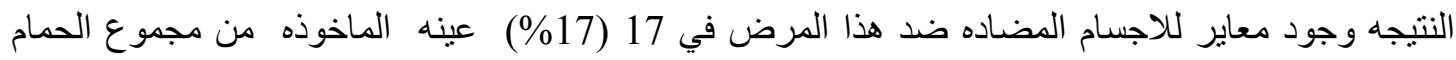

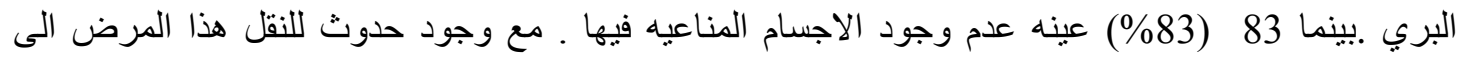

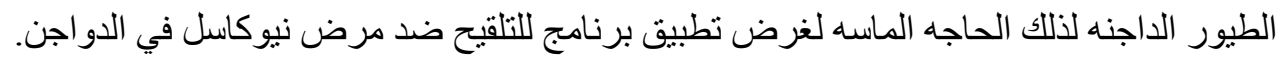

